\title{
Coarsening-Upward Cycles Origin-Another Autocyclic Explanation
}

\section{Damir Bucković* and Josip Filipović}

Department of Geology, Faculty of Science, University of Zagreb, Croatia

\begin{abstract}
Carbonate platform sediments are often organized in successive series of coarsening-upward cycles. In one coarsening upward cycle the grain size is increasing upward implying that the hydraulic energy required to deposit coarser and heavier grains must be higher than the energy required for the fine grains deposition. Two types of coarsening-upward cycles are analyzed: (1) cycles with peloidal-bioclastic upper cycle members, and (2) cycles with oolitic upper cycle members. These coarsening-upward cycles are regarded here as a consequence of the sea-bottom oscillations below and above the fair-weather wavebase but only triggered by autocyclic processes, creating simple model for the coarsening-upward cycle origin.
\end{abstract}

\section{Publication History:}

\section{Introduction}

\section{Samples and Methods}

Numerous studies of the effects of high-frequency relative sea-level changes in carbonates show that cycles are excellent indicators of sea-level fluctuations because their formation is highly dependent on many various parameters [1-7]. Thus, the cycle architecture depends on environmental factors that change periodically causing rapid facies changes trough time. These facies changes occur when a physical, chemical, and/or biological treshold is passed, and when the sediment
For the purpose of this paper one Lower Jurassic succession from Platak locality situated NE from town of Rijeka (Karst Dinarides Croatia) (Figure 1) were taken into account. Oriented rock samples are collected in the field using a rock pick. A minimum of three rock samples is taken from each sample site. Samples are first analyzed in their natural state and then as the thin sections under the microscope. One thin section is produced when a thin sliver of rock is cut from the

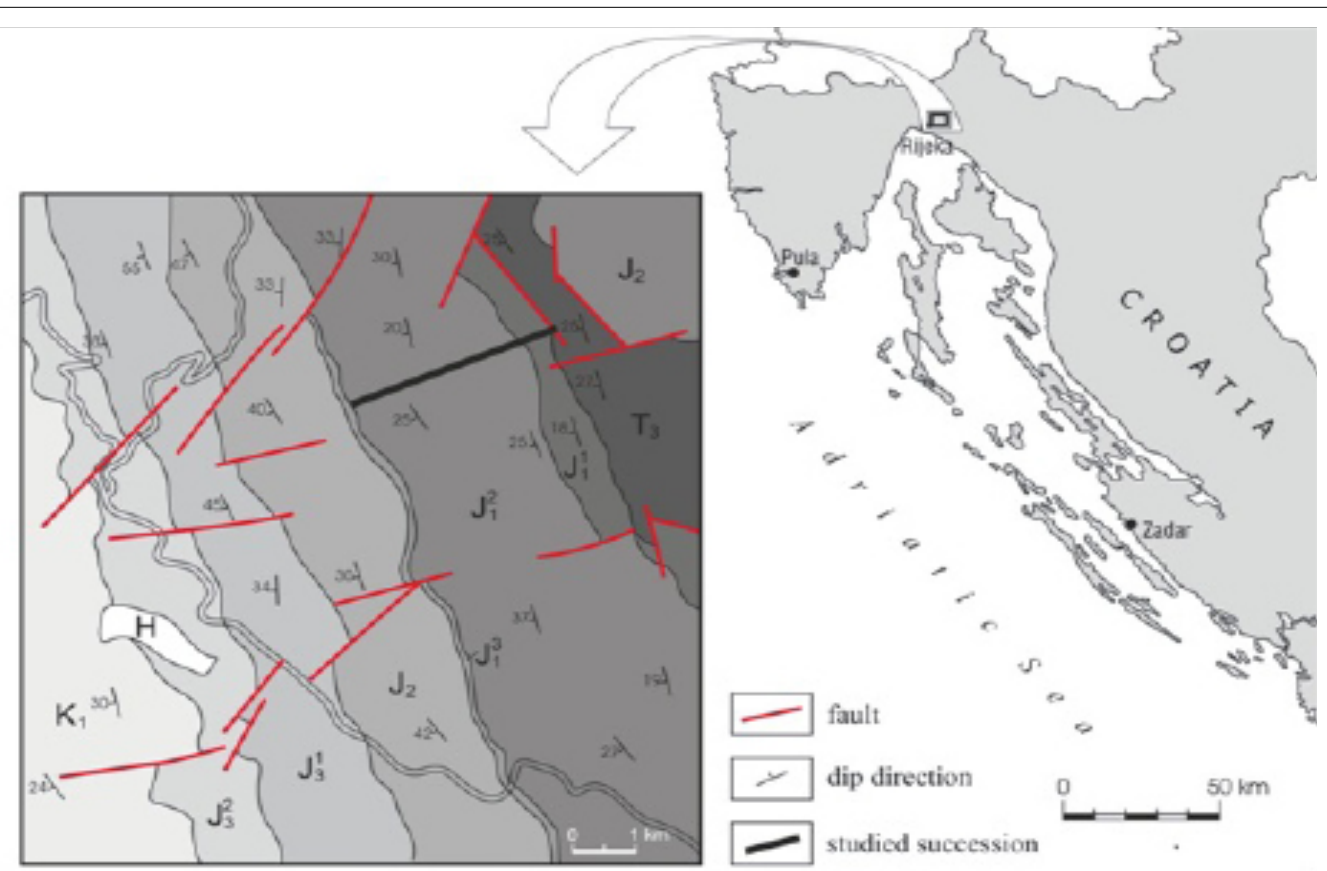

Figure 1: Geographical location and geologic background of studied succession area; Platak locality situated NE from town of Rijeka (Karst Dinarides - Croatia). Legend: $\mathrm{T}_{3}$ - Upper Triassic; $\mathrm{J}_{1}{ }^{1}$ - lower part of the Lower Jurassic; $\mathrm{J}_{1}{ }^{2}$ - middle part of the Lower Jurassic; $\mathrm{J}_{1}{ }^{3}$ - upper part of the Lower Jurassic; $\mathrm{J}_{2}$ - Middle Jurassic; $\mathrm{J}_{3}{ }^{1}$ - lower part of the Upper Jurassic; $\mathrm{J}_{3}{ }^{2}$ - upper part of the Upper Jurassic; $\mathrm{K}_{1}$ - Lower Cretaceous; $\mathrm{H}$ - Holocene.

acquires a new composition and texture [6]. The cyclic stacking pattern always reveals very similar characteristics. The general increase in grain size, decrease in mud content and sometimes even progresive change in style of sedimentary structures are commonly within single coarsening-upward cycle. Because of my frequent encounters with cyclic sedimentary signatures throughout the Karst Dinarides, especially within the Jurassic carbonate beds, one simple model for the entirely autoycyclic mechanism of coarsening-upward cycles origin can be proposed.
${ }^{*}$ Corresponding Author: Dr. Damir Bucković , Department of Geology, Faculty of Science, University of Zagreb, Croatia; E-mail: buckovic@geol.pmf.hr

Citation: Bucković D, Filipović J (2016) Coarsening-Upward Cycles OriginAnother Autocyclic Explanation. Int J Earth Envrion Sci 1: 102. doi: http://dx.doi. org/10.15344/ijees/2016/102

Copyright: (c) 2016 Bucković et al. This is an open-access article distributed under the terms of the Creative Commons Attribution License, which permits unrestricted use, distribution, and reproduction in any medium, provided the original author and source are credited. 
Citation: Bucković D, Filipović J (2016) Coarsening-Upward Cycles Origin-Another Autocyclic Explanation. Int J Earth Envrion Sci 1: 102. doi: http://dx.doi. org/10.15344/ijees/2016/102

Page 2 of 7

rock sample with a diamond saw and ground optically flat. It is then mounted on a glass slide and then ground smooth using progressively finer abrasive grit until the sample is only $30 \mu \mathrm{m}$ thick. Then the sample, now as a thin section, is ready for viewing and imaging under the microscope. Based on field and laboratory observation under the microscope, carbonate facies were identified within the successions and two types of coarsening-upward cycles have been recognized. These are cycles with the peloidal-bioclastic upper cycle members (1), and the cycles with the oolitic upper cycle members (2)(Figure-2).

\section{Results - Petrography of Carbonate Facies \\ Cycles with peloidal-bioclastic upper cycle members}

These coarsening-upward cycles contain mudstone or peloidalbioclastic wackestone as the lower cycle members. The thickness of the lower cycle members varies from 0.7-2 $\mathrm{m}$, whereas the upper cycle members range from 0.1-0.6 m. Mudstones and peloidal-bioclastic wackestones are composed of micrite with variable amounts of
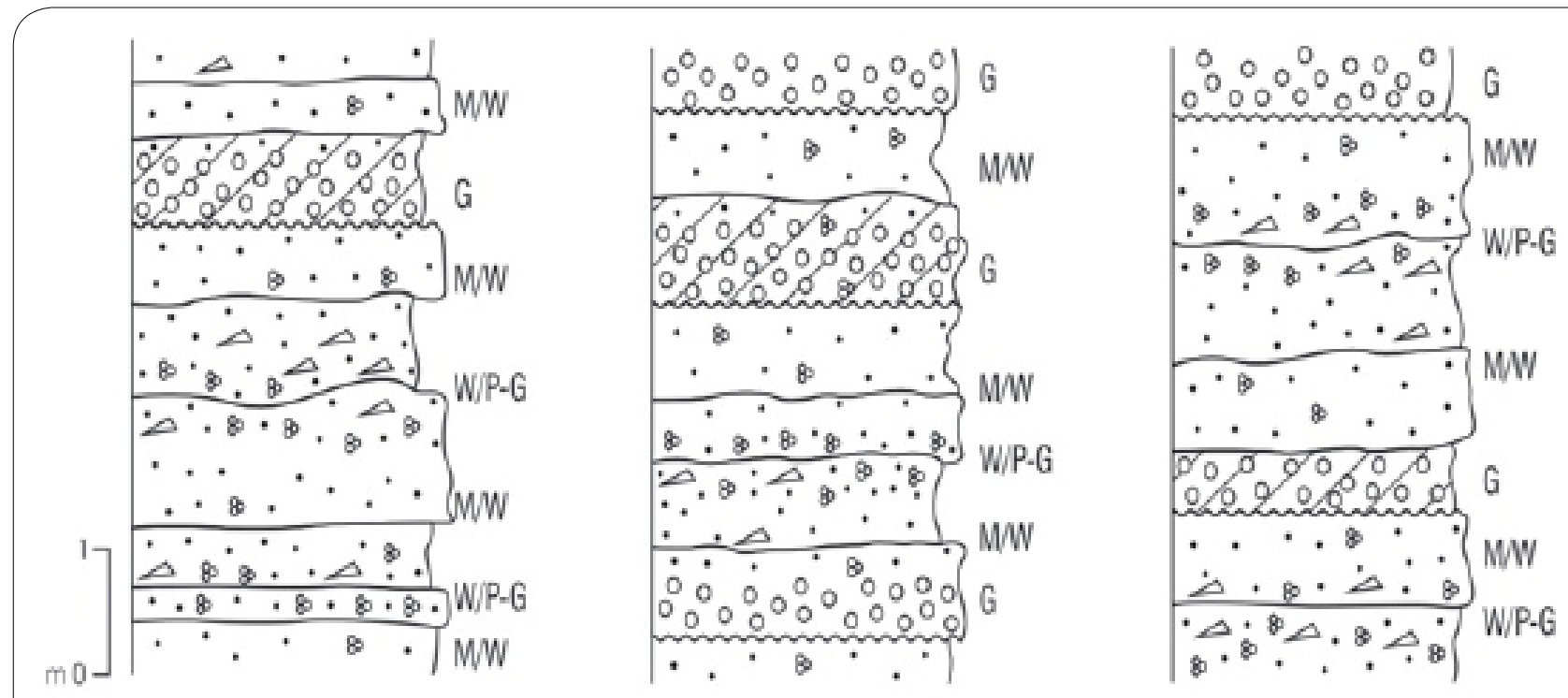
- Peloids and micrite
$\Delta$ Bioclasts
// Cross-bedding
M Mudstone
P Packstone
\& Foraminifers
- Ooids
Erosion surface
W Wackestone
G Grainstone

Figure 2: Typical Lower Jurassic coarsening-upward cycles observed within studied succession area.

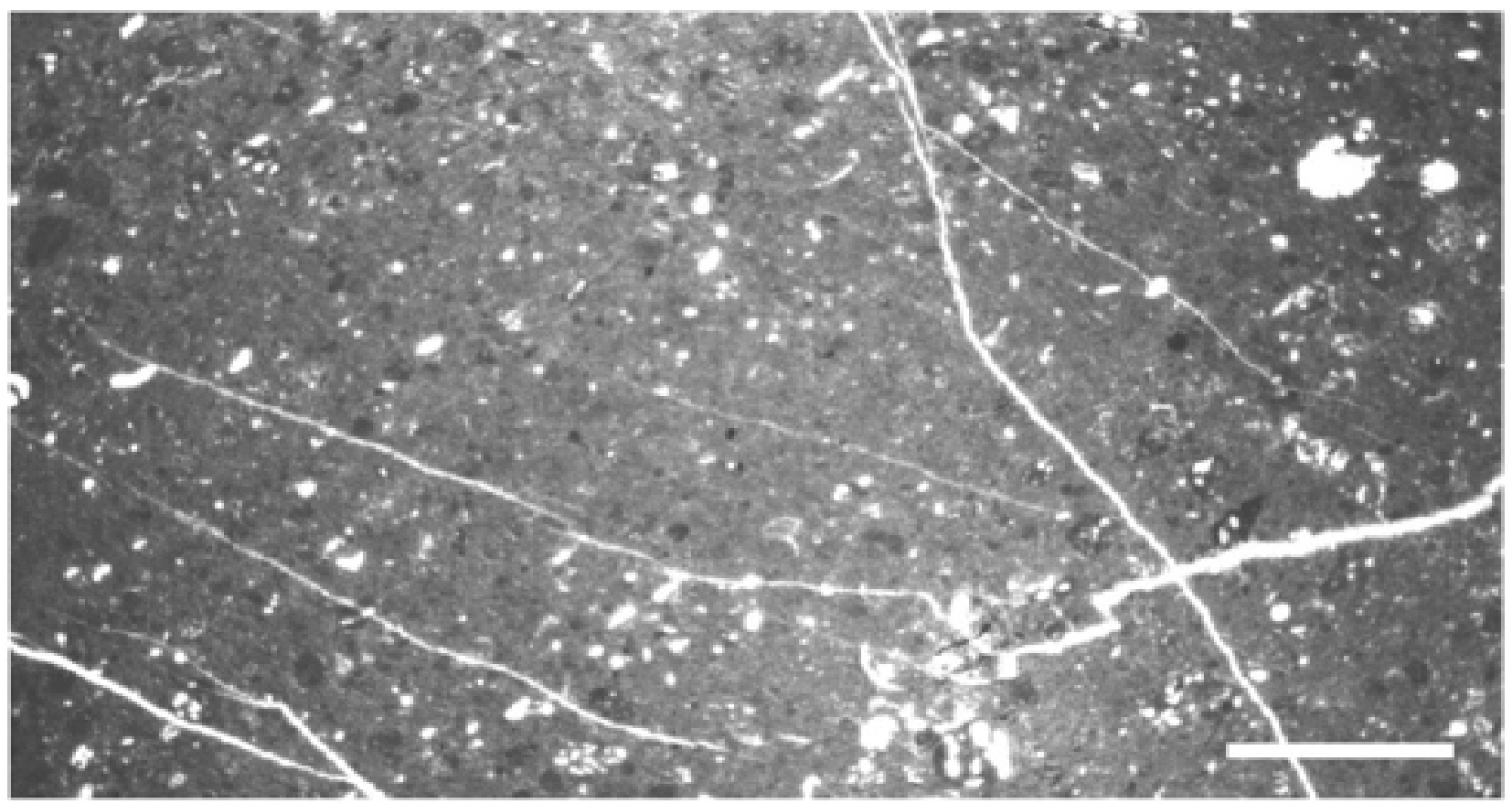

Figure 3: Peloidal-bioclastic wackestone; typical lithofacies of the lower cycle members within the cycles (1) and (2). Scale bar $1.6 \mathrm{~mm}$. 
Citation: Bucković D, Filipović J (2016) Coarsening-Upward Cycles Origin-Another Autocyclic Explanation. Int J Earth Envrion Sci 1: 102. doi: http://dx.doi. org/10.15344/ijees/2016/102

Page 3 of 7

peloids, molluscan and ostracode fragments and individual benthic foraminifera (Figure 3). Separate LLH stromatolitic laminae and laminoid fenestrae are sporadically present. Bioturbation occurs locally. Within these mud-rich limestone types, intercalations of horizontally laminated peloidal-bioclastic packstone-grainstone, 0.1 $0.3 \mathrm{~m}$ thick, can be occasionally found. Single horizontal $1-3 \mathrm{~mm}$ thick laminae are graded. These intercalations are always separated at their bottom by sharp, erosional surfaces. They have gradational upper boundaries into overlying mudstones or wackestones. Peloids, foraminifera, small echinoid and ostracode fragments embedded in micrite and/or drusy cement dominate. Elongated bioclasts are always oriented parallel to bedding. Coarse-grained particles are present within upper cycle members. These wackestone/packstones to grainstones are abundant in peloids, coarser molluscan and sporadic echinoderm bioclasts (Figure 4 and Figure 5). More rarely, they contain subrounded micritic intraclasts and concentric oncoids with bioclastic nuclei surrounded by few cryptocrystalline envelopes. Coarser-grained bioclasts are always more or less recrystallized and randomly oriented. Some beds contain rich foraminiferal debris. In places, horizontal lamination is present, when sharp and uneven erosional contacts with underlying unlaminated beds are visible.

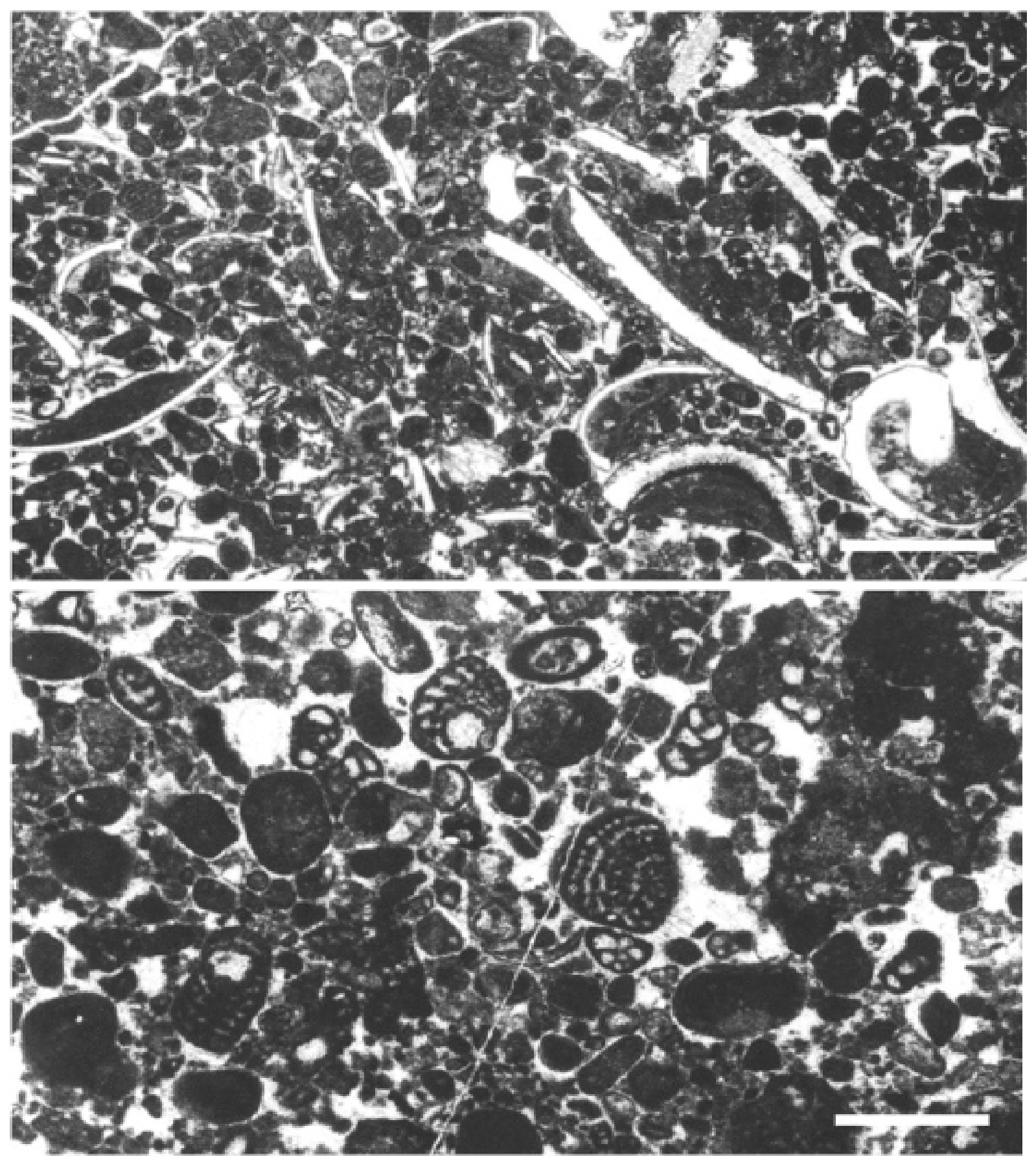

Figure 4 and 5 - Peloidal-bioclastic packstone to grainstone; typical lithofacies of the upper cycle members within the cycles (1). Figure 4 scale bar $1.6 \mathrm{~mm}$, Figure 5 - scale bar $0.8 \mathrm{~mm}$. 
Citation: Bucković D, Filipović J (2016) Coarsening-Upward Cycles Origin-Another Autocyclic Explanation. Int J Earth Envrion Sci 1: 102. doi: http://dx.doi. org/10.15344/ijees/2016/102

Page 4 of 7

By periodically changing conditions, from low-energy shallow subtidal to higher-energy subtidal above the fair-weather wave base, a series of coarsening-upward cycles have been produced. During low-energy shallow subtidal conditions with slow and constant rate of sediment accumulation a large amount of carbonate mud with rare bioclasts were deposited. A much more intensive production of various coarser-grained particles occurred during periodical subtidal shallowing above the fair-weather wave-base (see Discussion). Sporadic horizontal lamination observed within the packstone-grainstone intercalations and even wackestone/ packstone to grainstone beds was formed during periods of intensive unidirectional tidal and/or storm currents. These currents eroded the subtidal bottom, winnowed the muddy-peloidal-bioclastic material, removed the carbonate mud, oriented elongated bioclasts parallel to bedding, and formed the horizontal, graded laminae.

\section{Cycles with oolitic upper cycle members}

The same features as were described in the previous chapter characterize mudstones or peloidal-bioclastic wackestones as the lower members of these cycles. However, their thicknesses are generally smaller, amounting to $0.4-1.1 \mathrm{~m}$. The upper cycle member is represented by ooid grainstones and/or ooid-bioclastic packstones to grainstones. Ooid grainstones consist of well-sorted ooids with peloidal or bioclastic nuclei, surrounded by an envelope of radial fibrous fabric (Figure 6). The ooids are white to cream in color, have a pearly luster, and usually range in size from $0.2 \mathrm{~mm}$ to 1.0 $\mathrm{mm}$. They have frequently recrystallized envelopes and even nuclei. The diagenesis of these grainstones includes fibrous calcite on the surface of the ooids and drusy calcite spar in the intergranular pores. Sporadically, pore spaces are filled up by crystal silt. Among the ooids there are sporadic small molluscan fragments and foraminiferal tests. Distinct cross- and/or horizontal lamination can be sporadically observed. However, these structures are mostly hard to be recognized because of the well-sorted nature of the grainstones. The bases of oolitic members are commonly erosional surfaces. In drusy calcite spar or micritic matrix the ooid-bioclastic packstones to grainstones contain ooids and variety of poorly sorted, abraded and broken molluscan, echinoderm and hydrozoan fragments, as well as variously sized intraclasts (Figure 7). Elongated coarser-grained particles are mostly randomly oriented.

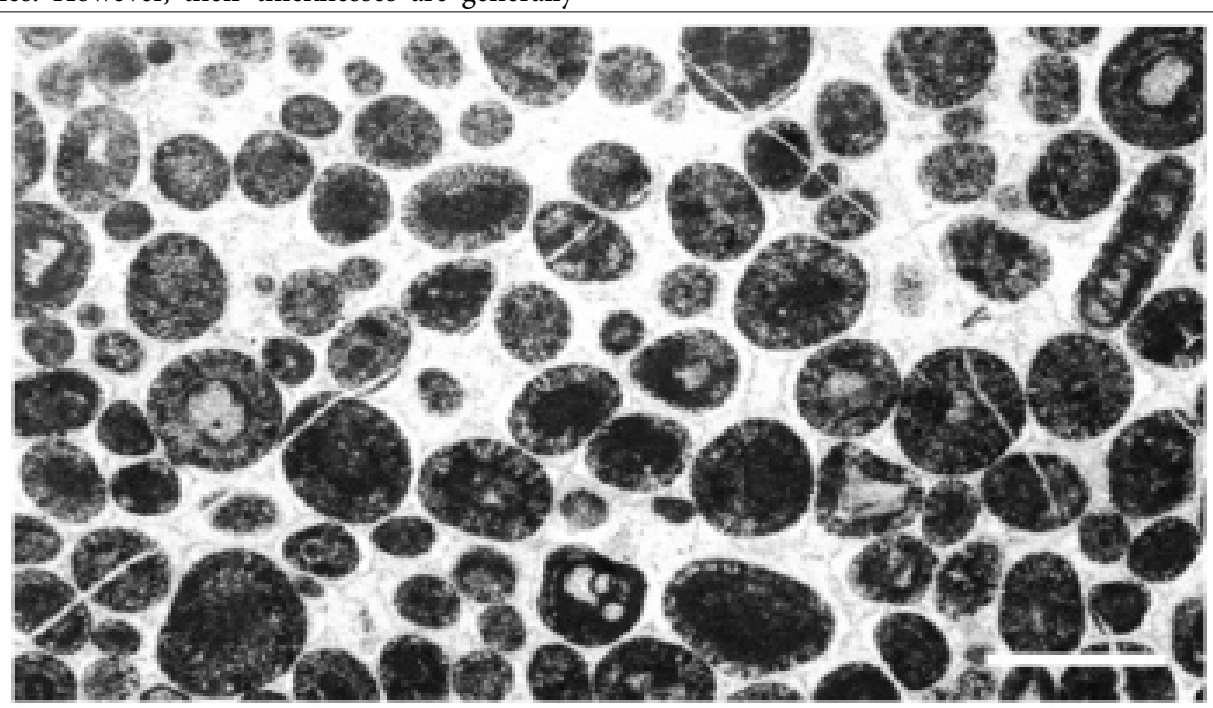

Figure 6: Ooid grainstone; typical lithofacies of the upper cycle members within the cycles (2). Scale bar $0.8 \mathrm{~mm}$.

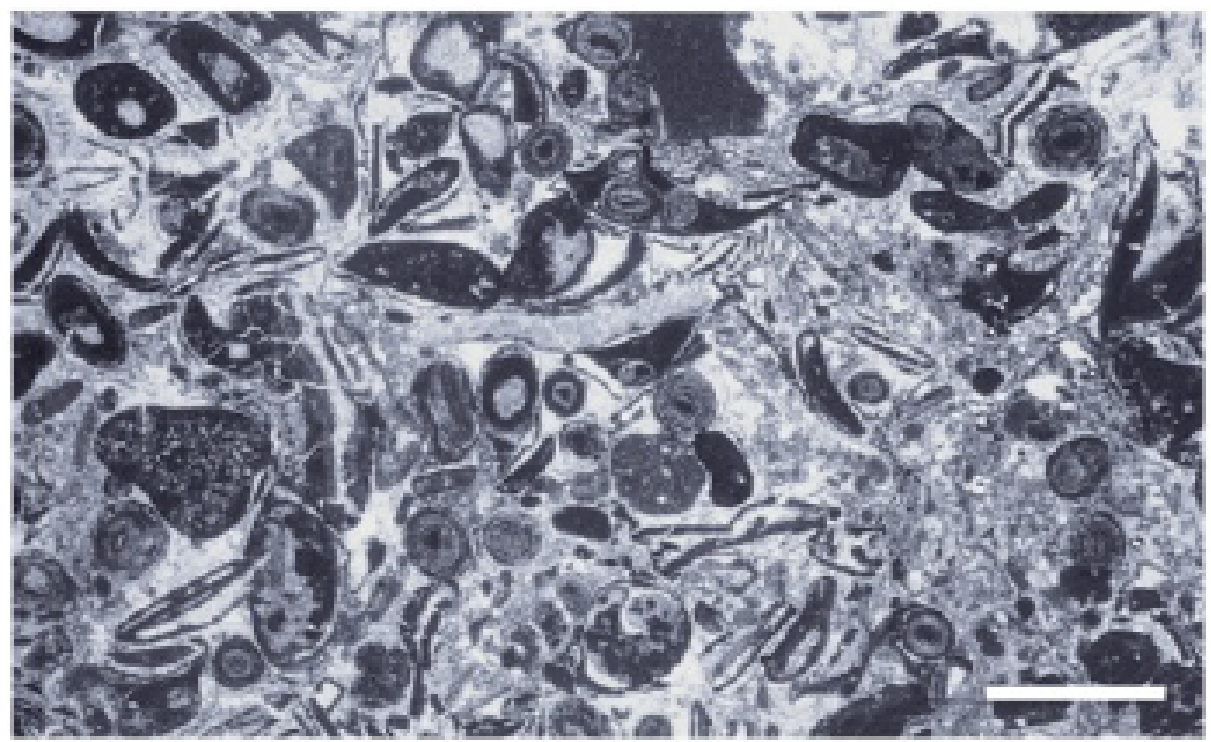

Figure 7: Ooid-bioclastic packstone to grainstone; another typical lithofacies of the upper cycle members within the cycles (2). Scale bar $1.6 \mathrm{~mm}$. 
These cycles also represent a sedimentary response to cyclic environmental changes from low-energy shallow subtidal to higher-energy subtidal above the fair-weather wave base. However, environmental conditions during the formation of the oolitic upper cycle members were different when compared with conditions where peloidal-bioclastic upper cycle members were deposited in (see Discussion). At first glance it is recognized by the frequent erosional surfaces underlying the oolites and by absence of micrite and peloids. That implies shallower and higher energy subtidal conditions of oolitic shoals that were migrated laterally over the relatively deeper subtidal environments. Their migration by tidal and/or storm currents of different energy led to formation of sporadic cross- and/ or horizontal lamination. Rare findings of crystal silt in pore spaces of oolites indicate neighboring presence of the vadose zone from which calcite crystals were washed and transported in suspension to the oolitic shoals.

\section{Discussion}

The high-frequency cycles described in this paper are usually referred to as parasequences [4]. They are often interpreted to be of allocyclic origin and to be caused by climatic fluctuations associated with Milankovitch cycles [8]. Milankovitch cycles are orbital cycles that modulate insolation and are commonly related to fluctuations of climate, whereby the waxing and waning of ice caps, especially during glaciations (such as nowadays), act as amplifier of the inherently weak insolation signal. Orbitally controlled waxing and waning of ice caps translate into high-frequency sea-level fluctuations that may lead to metre-scale shallowing- and coarsening upward cycles, [6, $9,10]$. However, it is difficult to correlate here studied cycles with Milankovitch cycles because during the Jurassic, ice in high latitudes probably was present but ice-volumes were not sufficient to induce important glacio-eustatic fluctuations [11-13], although volume changes of alpine glaciers could make a small contribution $[13,14]$ Additionally, the Early Jurassic is a time of climatic warming [15] because of rapid rise in $\mathrm{CO} 2$ levels caused by the outpouring of the Central Atlantic Magmatic Province as a result of the rifting of Pangea $[16,17]$. In such circumstances, there was probably no pronounced seasonality during Early Jurassic. However, it can be assumed that high-frequency sea-level fluctuations of allocyclic origin were present during Early Jurassic, but were small and thus hardly perceptible in the sedimentary record. Therefore, predominantly based on sedimentary mechanisms that are active in platform shallow-water environments, it can be interpreted that above described coarsening-upward cycles as being the result of autocyclic processes, but having in mind that some allocyclic signal was also present but for the time being hard to be recognized.

Large carbonate platforms, without prominent elevation differences, are characterized by small water depths (mainly less than $10 \mathrm{~m}$ ), and the fair-weather wave-base is at less than $5 \mathrm{~m}$ [18]. Judging from this, one can presume that successive series of coarsening-upward cycles may be a record of changes in water depth through varying sediment accumulation, when sea-bottom seemingly oscillates around the fairweather wave-base (the fair-weather wave-base - FWWB amounts to half of the wavelength - WL/2). This assumption is based on two wellknown facts: (1) under optimum conditions carbonate sediments can accumulate rapidly, resulting in high and mostly constant carbonate production rate $[19,20]$; and (2) carbonate production in modern depositional environments, as a rule, exceeds an average amount of platform subsidence and moderate eustatic sea-level rise [18] Typical sedimentation rate of modern carbonate deposits is $1 \mathrm{~m}$ per $1000 \mathrm{yr}$, typical subsidence rates of passive continental margins, where many ancient carbonate platforms developed, are 0.01-0.1 m per $1000 \mathrm{yr}$, and typical eustaic sea-level changes are $0.01 \mathrm{~m}$ per 1000 yr [18]. Rapid subsidence, generally fault-induced and major sea-level rises through glacial melting, is not included. From these, it can be presumed that facies differences, i.e. cycle architecture, are mainly the result of processes operating within thecarbonate platform realm. Among those processes, aggradation of subtidal carbonate deposits and progradation of small ooid shoals appear to be most important.

During periods when the water depth (i.e., accommodation space) (D) on many carbonate platform areas was greater than one-half of the wavelength $(\mathrm{D}>\mathrm{WL} / 2)$, there was no movement of sediment particles at the sea bottom (SB) (Figure 8a). Therefore, in quiet subtidal environments below the fair-weather wave-base, peloids and calcareous mud, as well as benthic forams occasionally associated with various bioclasts, were predominantly accumulated, producing muddy carbonate deposits (Figure $8 \mathrm{~b} 8 \mathrm{c}$, points $1-2$ and $4-5$ - tA) ("catch up" phase sensu [21]).

It is presumed that the carbonate production rate exceeded both the rate of subsidence and the rate of eustatic sea-level rise (i.e. relative sea-level rise). Such high carbonate accumulation rate caused gradual reducing of accommodation space, i.e., decrease of water depth. When the water depth became less than one-half of the wavelength $(\mathrm{D}<\mathrm{WL} / 2)$ (Figure $8 \mathrm{~b})$, there were occasional motions of sediment particles by waves on the sea-bottom. Under such shallower-water and higher energy conditions, various coarser-grained calcareous particles were formed, producing grain supported deposits (Figure 8 c; point 2). With continuing carbonate production, accommodation space further decreased and the sea-bottom continues to aggrade (Figure 8c; points 2-3 - tB) ("keep up" phase sensu [21]). Yet, such environment with agitated water, supersaturated with $\mathrm{CaCO}_{3}$, became unfavorable for the majority of carbonate-producing benthic organisms (e.g. foraminifera, mollusks). Also, highly oxygenated pore waters and high water exchange rates enhanced the process of cementation. Under such conditions, the rate of new carbonate sediment production slowed down, i.e. the carbonate accumulation was easily outpaced by continued relative sea-level rise, and seabottom was lowered below the fair-weather wave base (Figure 8c; points 3-4 - lag). After this "lag phase" [22, 23], carbonate-producing organisms (mostly mass faecal pellets producers, e.g. worms, ostracodes, gastropods) colonized the sea-bottom drowned below the fair-weather wave base, and carbonate production was re-established (Figure 8c; point 4) ("start-up" phase sensu [21]; or "lag phase" sensu $[22,23])$; a new cycle with a muddy lower member started to accumulate (Figure 8c; points 4-5) ("catch-up" phase sensu [21]). Such autocyclic mechanism would explain the origin of the coarseningupward cycles with peloidal-bioclastic upper cycle members.

In contrast to that, environmental conditions within sporadically presented subtidal topographic highs were rather different (Figuress. $8 \mathrm{~d}-\mathrm{f}$ ). In these places, the water depth was smaller and the wavelength was consequently shortened, so the sea-bottom (SB) was positioned closer to the fair-weather wave-base (FWWB) (Figure 8d). Thus, when the water depth became less than one-half of the wavelength $(\mathrm{D}<\mathrm{WL} / 2)$, water temperature and $\mathrm{pH}$ as well as the carbonate saturation level and water energy increased, favoring the formation of ooids, e.g. [5] (Figure 8e). In such conditions, the ooids are in constant motion allowing them to grow around a nucleus forming an oolitic shoal. With continuing production of ooids the accommodation space decreases (Figure 8f; points 2-3 - tB). When oolitic shoals 
Citation: Bucković D, Filipović J (2016) Coarsening-Upward Cycles Origin-Another Autocyclic Explanation. Int J Earth Envrion Sci 1: 102. doi: http://dx.doi. org/10.15344/ijees/2016/102

Page 6 of 7

aggraded close to the sea level, they begin to prograde laterally (Figure 8f; points 3-4) under influence of tidal and/or storm currents (when distinct cross- and/or horizontal lamination was formed), covering the adjacent deposits below and/or above the fair-weather wave-base and forming the coarsening-upward cycles with distinct upper oolitic and/or oolitic-bioclastic cycle members. Therefore, the occurrence of cycles with ooids reflects the oolitic shoal progradations. These oolitic shoal progradations were random, episodic processes that depended on physical factors working in the sedimentary environment. Among those, the most important was the formation of subtidal topographic highs on which the water depth was reduced (see above for explanation). The topographic highs in the shallow carbonate platform realm would develop through sediment trapping by organisms (e.g. fleshy algae), or through slight tectonic uplifts.
However, as evidences for the formation of barriers through sediment trapping in the investigated Lower Jurassic succession were not noticed, we assume that small-scale synsedimentary uplifts were a more likely scenario. These small-scale uplifts were random events, with no predictable periodicity and place of occurring. Thus, in periods when oolitic shoals prograded over the subtidal below the fair-weather wave-base, one coarsening-upward cycle with ooid grainstone as the upper cycle member was formed. Analogously, in periods when oolitic shoals prograded over the subtidal above the fairweather wave-base, one coarsening-upward cycle with ooid-bioclastic packstones to grainstones as the upper cycle member was formed. In periods when high energy storm events triggered progradation, i.e. rapid migration of oolites, these currents succeeded to erode subtidal bottom when erosive bases of the oolites were formed.

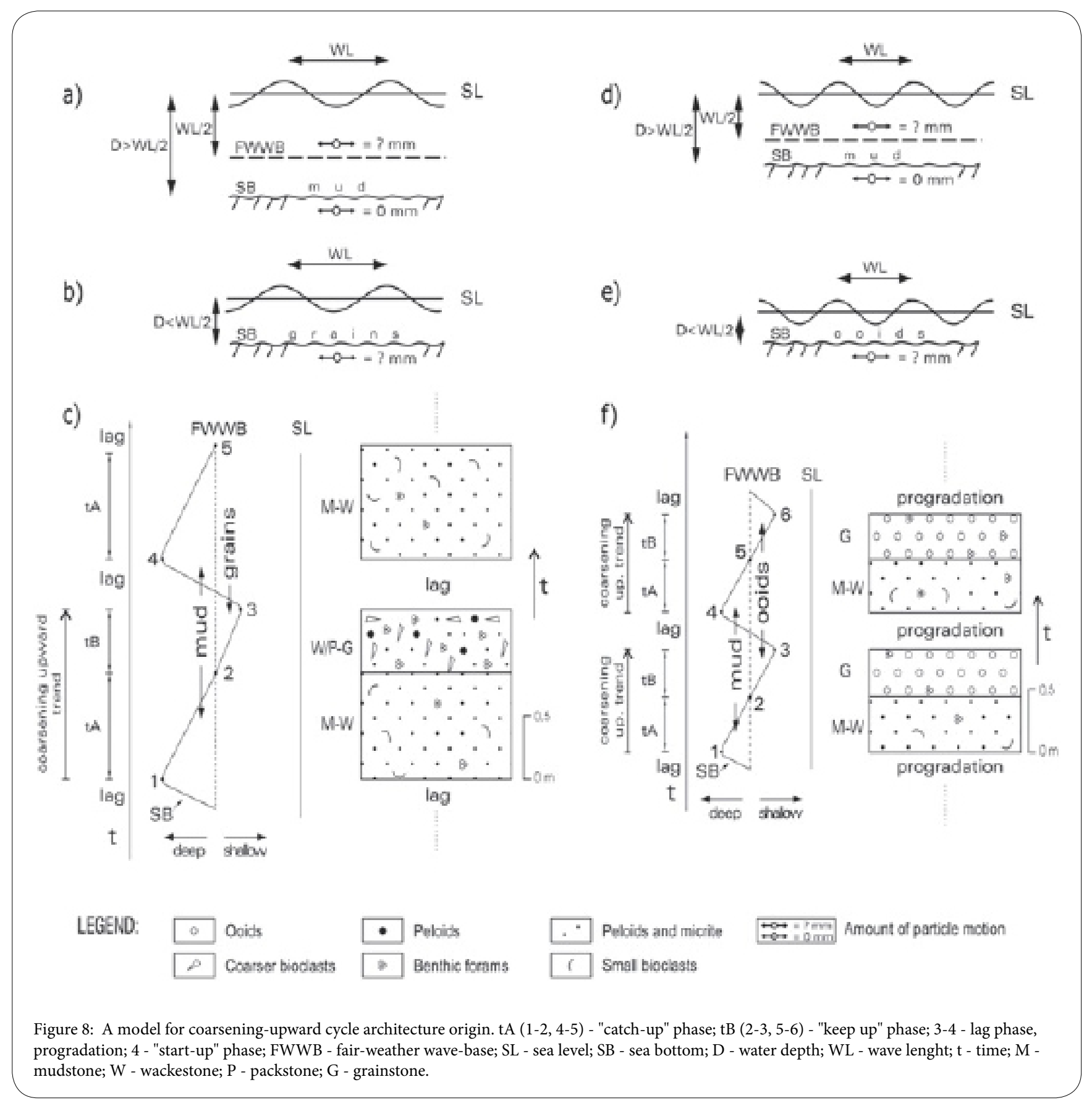


Citation: Bucković D, Filipović J (2016) Coarsening-Upward Cycles Origin-Another Autocyclic Explanation. Int J Earth Envrion Sci 1: 102. doi: http://dx.doi. org/10.15344/ijees/2016/102

Page 7 of 7

During periods without oolitic shoal progradations, only vertical aggradation of subtidal carbonate deposits occurred, producing successive series of coarsening-upward cycles with peloidal-bioclastic upper cycle members.

\section{Conclusion}

The examined coarsening-upward cycles were formed within the shallow-water realm of the carbonate platform area. They reveal coarsening-upward trend from the subtidal below the fair-weather wave-base to the subtidal above the fair-weather wave-base as the predominant response to the autocyclicity in the sedimentary environment. Gradual aggradation of the muddy carbonate material, deposited below the fair-weather wave-base reduced the accommodation space, causing the sea bottom to rise above the fairweather wave-base. Here, more grainy carbonates were deposited, creating one coarsening upward cycle with mudstones or peloidalbioclastic wackestones as the lower cycle member and peloidalbioclastic wackestone/packstones to grainstones as the upper cycle member. During the "lag phase", the sea bottom has sunk belowthe fair-weather wave-base, what enabled the formation of the next coarsening-upward cycle. The progradations of neighboring oolitic shoals periodically and randomly interrupted this process. Oolitic shoals that were sporadically formed on topographic highs within the subtidal area prograded over the surrounding environment below or above the fair-weather wave-base, producing sporadic coarseningupward cycles with ooid grainstones and/or ooid-bioclastic packstones to grainstones as the upper cycle member. Therefore, coarsening-upward architecture resulted from interplay of repeated sediment aggradations, interrupted by periodical and random oolitic shoals progradations.

\section{Acknowledgement}

We thank the editor and two anonymous reviewers for their constructive comments, which helped us to improve the manuscript.

\section{References}

1. Hays JD, Imbrie J, Shackleton NJ (1976) Variations in the Earth's orbit: pacemakerof the ice ages. Science 194: 1121-1132.

2. Goodwin PW, Anderson EJ (1985) Punctuated aggradational cycles: a generalhypothesis of episodic stratigraphic accumulation. J Geol 93: 515533.

3. Grotzinger JP (1986) Cyclicity and pale environmental dynamics, Rocknest platform,northwest Canada. Bull Geol Soc Am 97: 1208-1231.

4. Goldhammer RK, Oswald EJ, Dunn PA (1990) Forward modeling of highfrequency, depositional sequences: an example from Middle Pennsylvanian shelfcarbonates of the SW Paradox Basin, Honnacker Trail, Utah. Abstr Am Assoc Pet Geol Bull 74: 663.

5. Gonzales R (1996) Response of shallow-marine carbonate facies to third-order and high-frequency sea-level fluctuations: Hauptrogenstein Formation, northernSwitzerland. Sedimen Geol 102: 111-130.

6. Strasser A, Pittet B, Hillgärtner H, Pasquier JB (1999) Depositiona sequences inshallow carbonate-dominated sedimentary systems: concepts for a high-resolutionanalysis. Sedimentary Geol 128: 201-221.

7. Egenhoff SO, Peterhänsel A, Bechstädt T, Zühlke R, Grötsch J (1999) Faciesarchitecture of an isolated carbonate platform: tracing the cycles of the Latemar(Middle Triassic, northern Italy). Sedimentol 46: 893-912.
8. Vail PR, Audemard F, Bowman SA, Eisner PN, Perez-Cruz C (1991) Thestratigraphic signatures of tectonics eustasy and sedimentology - an Overview. Cycles and events in stratigraphy,Springer-Verlag 617-659.

9. Strasser A (1991) Lagoonal-peritidal sequences in carbonate environments: autocyclicand allocyclic processes. Cyclesand events in stratigraphy. Springer-Verlag 709-721.

10. Goldhammer RK, Dunn PA, Hardie LA (1993) Depositional cycles, compositesea-level changes, cycle stacking patterns, and the hierarchy of stratigraphic forcing:examples from Alpine Triassic platform carbonates. Geol Soc Am Bull 102: 525-562.

11. Frakes LA, Francis JE, Syktus JI (1992) Climate Modes of the Phanerozoic. Cambridge Univ Press 1-274.

12. Eyles N (1993) Earth's glacial record and its tectonic setting. Earth Sci Rev 35: $1-248$.

13. Valdes PJ, Sellwood BW, Price GD (1995) Modelling Late Jurassic Milankovitchclimate variations. Orbital ForcingTimescales and Cyclostratigraphy. Geol Soc Spec Publ 85: 115-132.

14. Fairbridge RE (1976) Convergence of evidence on climatic change and ice ages. AnnNY Acad Sci 91: 542-579.

15. Hallam A, Wignall PB (1999) Mass extinctions and sea-level changes. Earth Sci Rev 48: 217-250.

16. Nance RD, Murphy JD (1994) Orogenic style and the configuration ofsupercontinents. Pangea:global environments and resources. Canadian Soc Petrol Geol Mem 17: 49-65.

17. Marzoli A, Renne PR, Piccirillo EM, Ernesto M, Bellieni G, et al. (1999) Extensive 200-milion-year-old continental flood basalts of the Central AtlanticMagmatic Province. Sci 284: 616-618.

18. Tucker ME, Wright PV (1990) Carbonate sedimentology. Blackwell 1-482.

19. Smith SV (1973) Carbon dioxide dynamics: a record of organic carbon production, respiration and calcification in the Enewetak windward reef flat community. Limnol Oceanogr 18: 106-120.

20. Hallock P (1981) Production of carbonate sediments by selected large benthicforaminifera on two Pacific coral reefs. J. Sedim. Petrol. 51: 467474.

21. Kendall CGStC, Schlager W (1981) Carbonates and relative changes in sea level. Marine Geol 44: 181-212.

22. Read JP, Grotzinger JP, Bova JA, Koerschner WF (1986) Models for generationof carbonate cycles. Geology 14: 107-110.

23. Schlager W (1992) Sedimentology and sequence stratigraphy of reefs and carbonate platforms. Am Assoc Petrol. Geol Contin Educ Course Note Ser 34. 